\title{
Prevalence of respiratory symptoms and disorders among rice mill workers in India
}

\author{
Tirthankar Ghosh • Somnath Gangopadhyay • \\ Banibrata Das
}

Received: 6 August 2013/ Accepted: 17 February 2014/Published online: 8 March 2014

(c) The Japanese Society for Hygiene 2014

\begin{abstract}
Objectives Lung function tests have become an integral part of assessment of pulmonary disease. Diseases of the respiratory system induced by occupational dusts are influenced by the duration of exposure. The aim of the study is to investigate the impairment of lung function and prevalence of respiratory symptoms among the rice mill workers.

Methods A total of 120 rice mill workers from three districts of Karnataka were included in this study. Fifty urban dwellers from the same socio-economic level were selected as controls. The study included clinical examination, assessment of respiratory symptoms, pulmonary function test, measurement of peak expiratory flow rate, absolute eosinophil count, ESR estimation, total IgE estimation and radiographic test.

Results The present study has shown that the rice mill workers complained of several types of respiratory

\section{T. Ghosh}

Department of Physiology, Maitri College of Dentistry \& Research Center, Anjora, Durg, Chhattisgarh, India

e-mail: tirthag@gmail.com

\section{S. Gangopadhyay}

Occupational Ergonomics Laboratory, Department of Physiology, University College Science and Technology, University of Calcutta, Kolkata, India

B. Das

Department of Physiology, South Calcutta Girls' College, University of Calcutta, Kolkata, India

B. Das $(\bowtie)$

100 Biplabi Ganesh Ghosh Sarani, Post-Bhadrakali,

Dist Hooghly, West Bengal 712232, India

e-mail: dr.banibrata@gmail.com
\end{abstract}

disorders like phlegm (40.8\%), dyspnea (44.2\%), chest tightness $(26.7 \%)$, cough $(21.7 \%)$, and nose irritation $(27.5 \%)$. Rice mill workers exposed to dust presented significantly $(p<0.05)$ lower levels of FVC $(3.44 \pm 0.11)$, $\mathrm{FEV}_{1}(2.73 \pm 0.15)$ and PEFR (304.95 \pm 28.79$)$ than the controls. The rice mill workers are having significantly higher absolute eosinophil counts, total IgE and ESR than control groups. The hematological findings suggest that the harmful effects may be linked to both non-specific irritation and allergic responses to rice husk dust among rice mill workers.

Conclusion Dust exposure in the working environment affects the lung function values and increased the respiratory symptoms among the rice mill workers.

Keywords Rice mill worker - Respiratory symptoms · Lung volume $\cdot$ Allergy

\section{Introduction}

The respiratory health effects have been documented in workers exposed to a variety of dusts in small- and largescale industries, which generate dusts during their production process [1]. Diseases of the respiratory system induced by occupational dusts are influenced by the type of dust and duration of exposure [2]. Occupational diseases are caused by pathologic responses of the workers to their working environment [3]. Rice mill workers are potentially exposed to organic and inorganic dusts and synthetic chemicals that may have adverse effects on their respiratory health [4]. Several reports have suggested that unprotected dust exposures in agricultural settings may lead to pulmonary fibrosis [5-7]. Grain dust has a long history of association with disease, and its adverse effects 
on various organs such as eyes, nose, skin, lung and airways have been described [8].

A rice grain is made up of an external husk layer, a bran layer, and the endosperm. The husk layer (lemma and palea) accounts for $20 \%$ of the weight of paddy. The husk layer is removed from the paddy by friction and the process is called de-husking or de-hulling. De-husking was traditionally done using mortar and pestles but, in modern rice mills, it is done by passing the paddy grains between two abrasive surfaces that move at different speeds. After separating the husk from paddy, the husk is removed by suction (aspirated) and then transported to a storage dump outside the milling plant.

There are a number of common exposures that will lead to respiratory illness. These include organic dusts and other respiratory hazards that include inorganic dusts, pesticides and agrochemicals [9]. Farmers and individuals involved in agricultural work have potential exposure to a very wide range of agents-inorganic dusts from soil, organic dusts from microorganisms, mycotoxins, allergens, pesticides, etc. These exposures occur during harvesting, processing or storing grains or other plant matter, or when the soil, plants or stables are treated with chemical agents such as pesticides and disinfectants. The complex inorganic fraction of this dust comes chiefly from the soil [10].

However, it should be noted that most occupational exposures to airborne hazards can be greatly reduced or eliminated through engineering controls, such as improving ventilation, good work practices and use of personal protective equipment such as properly selected and maintained respirators. Numerous respiratory diseases of workers exposed to grain dusts have been described in the literature [11], particularly in relation to farmer's lung [12], but only a few reports are available on the effects of occupational exposure to grain dusts in the grain transformation industry [13-15]. A large quantity of dust is generated into the environment of grain processing industries when agricultural commodities are converted into an edible form for human consumption, thus causing a potential health risk to workers due to inhalation of vegetable dusts. There are few reports which deal with exposure to airborne aflatoxin through inhalation $[16,17]$.

Occupational exposure to organic dust and endotoxin may cause various respiratory diseases, including asthma, allergic alveolitis, chronic bronchitis, toxic pneumonitis [18-21] as well as acute and/or chronic lung function impairment [22-25]. Several cross-sectional studies in different work environments were conducted to assess the relationship between occupational exposure to bio-aerosols and over-shift changes in lung function. In occupational respiratory diseases, spirometry is one of the most important diagnostic tools. It is the most widely used most basic, effort-dependent pulmonary function test (PFT) and can measure the effects of restriction or obstruction on lung function [24, 26]. For example, examination of a group of potato processing workers indicated an across-shift decrease in $\mathrm{FEV}_{1}$ and MEF values associated with exposure to airborne endotoxin [27, 28]. Another study indicated a dose-response relationship between wood dust concentration and post-shift reduction of $\mathrm{FEV}_{1}$, $\mathrm{FEV}_{25-75} \%$ and FVC.

Peak expiratory flow rate (PEFR) is an important parameter to measure that indicates resistance and severity of airflow obstruction and in the management of bronchial asthma. Exposures to dust in the agricultural fields and with increasing use of chemicals either as fertilizers or pesticides, agricultural workers are exposed to toxic hazards from these chemicals and particulate pollutants and thus face a multitude of health problems [29].

The purpose of the present study was to estimate the prevalence of respiratory symptoms and respiratory disorders among workers exposed to dusts in the rice mills at Karnataka.

\section{Subjects and methods}

\section{Subjects}

The group of 120 (46 males and 74 females) workers occupationally exposed to dust from rice mills in 3 districts (Davangere, Raichur and Bellary) of Karnataka was included in the study. Additionally, 50 urban dwellers from the same socio-economic level, not exposed to any kind of organic dust, were selected as controls. The group consisted of 24 males and 26 females. The study was performed during the period of March 2008 to November 2008.

Before conducting the study, written informed consent was taken from the rice mill workers. Prior permission and ethical approval was also obtained from relevant authorities before commencement of the study. Before conducting the survey, a written permission on the project was obtained from Institutional Human Ethical Clearance Committee over the Indian Council of Medical Research Guidelines.

\section{General physical examination}

A routine physical examination was conducted to identify the signs for respiratory system involvement like clubbing, anemia and signs of allergy that included pale and oedematous nasal mucosa, swollen turbinates and a thin, watery or mucoid discharge. Ocular features are, oedema of eye lids, congestion of conjunctiva and watering of eyes. 


\section{Clinical examination}

A thorough clinical examination including examination of the ears, nose and throat was made in all cases using the standard head mirror, followed by respiratory system examination systematically by inspection, palpation, percussion and auscultation.

Assessment of respiratory symptoms (questionnaire examination)

Prior to spirometry, all workers included in this study completed a self-administered questionnaire on chronic bronchitis symptoms based on the British Medical Research Council's Questionnaire (1960). In addition, employees completed a questionnaire regarding sociodemographic information (age, duration of employment, occupation, smoking habit).

The MRC questionnaire has been tested in a variety of different conditions and has been shown to be a reproducible and accurate way of collecting such information. Questionnaires were administered face-to-face and consisted of three parts, including: (1) personal and work characteristics; (2) respiratory health symptoms, which included items such as symptoms of dyspnea, cough, phlegm, eye symptoms, time-of-onset of symptoms, duration of symptoms, relation of symptoms to work, i.e., whether they were worse at work or at home or whether they only arose exclusively at work, whether treatment had been received for the symptoms (3) smoking habits. A trained interviewer interviewed each worker during working time.

\section{Definitions of respiratory symptoms}

- Chest tightness Tightness or constriction of the chest occurring any time during the work shift and on any workday, without being worse.

- Chronic phlegm Sputum production occurring on most (5) days a week for a minimum of 3 months a year for at least two consecutive years.

- Chronic cough Cough without sputum occurring on most (5) days a week for a minimum of 3 months a year for at least two consecutive years.

- Dyspnea (2+) Having to walk slower than a person of the same age at an ordinary pace on level ground because of breathlessness.

Pulmonary function test (PFT)

The examinations were performed with the use of SpirovitSp-10 (Schiller, Switzerland). Three successive recordings of vital capacity (VC) and forced vital capacity (FVC), forced expiratory volume in the first second $\left(\mathrm{FEV}_{1}\right)$ and force expiratory ratio $\left[\mathrm{FEV}_{1} / \mathrm{FVC}(\%)\right]$ were performed in the standing position and the best of the three ratings was recorded.

\section{Peak expiratory flow rate (PEFR)}

Measurement of PEFR was done with a mini-Wright's peak flow meter (Clement Clarke International, UK). Prior to recording the subjects' $\mathrm{PEFR}$, the use of the instrument was repeatedly demonstrated and explained to them. The PEFR test was performed in the standing position with the peak flow meter held horizontally. The subjects were asked to take as deep a breath as possible and then to blow out as hard and as quickly as possible. The best of three ratings was recorded.

Absolute eosinophil count

Blood samples $(2 \mathrm{ml})$ were collected by clean sterile EDTA vials at the study area and sent to the central laboratory for absolute eosinophil count. The cell count was obtained using the semi-automated cell counter (BMD EXCELL 18-Danam Semi-Automatic, Medex Laboratories Ltd, Canada).

Erythrocyte sedimentation rate (ESR) estimation

The automated ESR analyzer (StaRRsed Compact, Mechatronics Instruments BV, Netherland) was used to estimate the ESR, which produces a true Westergren method result.

\section{Serum total $\operatorname{IgE}$ estimation}

Total IgE levels were measured using the ImmunoCAP1000 (Pharmacia Diagnostics AB, MI) for the quantitative measurement of serum IgE in the humans. Total IgE levels are represented as IU/ml.

\section{Radiographic test}

Plain standard erect posterior anterior chest radiographs were taken for each subject and control, using conventional exposure of between 60 and $80 \mathrm{kV}$ without an absorption grid. The focal film distance was fixed at $3 \mathrm{~m}$, with centering point between the fourth or fifth thoracic vertebra. Exposures were obtained at full suspended inspiration with elbows flexed, back of hands placed on hips, and elbows pushed gently forwards. Exposure time was between 0-05 and $0-08 \mathrm{~s}$.

Statistical analysis

A two-tailed $\chi^{2}$ test of independence was used to determine whether or not the test item had any significant association 
with respiratory symptoms between rice mill workers and control subjects. A two-tailed $\chi^{2}$ test of independence was also used to determine the respiratory symptoms of the rice mill workers according to the duration of exposure. Student's $t$ test was used to determine whether there are any significant differences between the lung function values of rice mill workers and control subjects. One-way ANOVA and post hoc analysis were used to determine the lung function values of the rice mill workers according to the duration of exposure. Student's $t$ test and Chi-square test were also used to determine the difference of hematological and immunological parameters and radiological findings between rice mill workers and control subjects, respectively. Statistical analysis was performed using the statistical package PRIMER OF BIOSTATISTICS (Primer of Biostatistics 5.0.msi, Msi Version 1.20.1827.0, Primer for Windows, McGraw-Hill).

\section{Results}

Demographic factors relating to the study population, including age, weight and height are given in Table 1. There was no significant difference between the mean age of the rice mill workers $(39.4 \pm 2.15)$ and the controls $(38.7 \pm 2.15)$, also in height and weight. The years of experience of the rice mill workers were calculated from the questionnaire and the average workers are having 15.9 years of experience. It is observed that the rice mill workers work 7 days in a week. The average duration of

Table 1 General information about 120 rice mill workers and 50 controls

\begin{tabular}{|c|c|c|c|}
\hline Variables & $\begin{array}{l}\text { Rice mill } \\
\text { workers }\end{array}$ & Controls & $p$ value \\
\hline Age (years) & $(39.4 \pm 2.15)$ & $(38.7 \pm 2.15)$ & $\begin{array}{l}\text { Not } \\
\text { significant }\end{array}$ \\
\hline Height $(\mathrm{cm})$ & $(169.1 \pm 1.09)$ & $(168.8 \pm 1.18)$ & $\begin{array}{l}\text { Not } \\
\text { significant }\end{array}$ \\
\hline Weight $(\mathrm{kg})$ & $(63.13 \pm 0.79)$ & $(62.52 \pm 1.51)$ & $\begin{array}{l}\text { Not } \\
\text { significant }\end{array}$ \\
\hline $\begin{array}{l}\text { Years of } \\
\text { experience }\end{array}$ & $(15.9 \pm 7.22)$ & $(15.6 \pm 4.14)$ & $\begin{array}{l}\text { Not } \\
\quad \text { significant }\end{array}$ \\
\hline $\begin{array}{l}\text { Duration of work } \\
\text { per day (h) }\end{array}$ & $(12 \pm 2.11)$ & $(8 \pm 1.26)$ & $\begin{array}{l}\text { Not } \\
\text { significant }\end{array}$ \\
\hline $\begin{array}{l}\text { Duration of rest per } \\
\text { day (h) }\end{array}$ & $(1.5 \pm 1.00)$ & $(1 \pm 1.00)$ & $\begin{array}{l}\text { Not } \\
\text { significant }\end{array}$ \\
\hline $\begin{array}{l}\text { Number of working } \\
\text { days in a week }\end{array}$ & 7 & 6 & $\begin{array}{l}\text { Not } \\
\text { significant }\end{array}$ \\
\hline Smokers & 62 & 29 & $\chi^{2}=0.017$ \\
\hline Non-smokers & 58 & 21 & $\begin{array}{l}p=0.898 \\
\text { Not } \\
\quad \text { significant }\end{array}$ \\
\hline
\end{tabular}

work per day is $12 \mathrm{~h}$ that varies on the demand of work according to the paddy season. The smoking habits of the workers and controls are compared in Table 1; there was no significant difference.

Table 2 shows the proportion of respiratory symptoms reported by the rice mill workers and controls. A significantly greater proportion of the rice mill workers complained of phlegm $(40.8 \%)$, dyspnea $(44.2 \%)$, chest tightness $(26.7 \%)$, cough $(21.7 \%)$, and nose irritation $(27.5 \%)$.

Table 3 shows the proportion of respiratory symptoms reported by the rice mill workers by duration of employment. Respiratory symptoms were higher in workers with duration of employment longer than 20 years, when compared with the other two groups; whereas, workers with a work history ranging from 10 to 19 years in the industries appeared to be less symptomatic compared with the groups with work history $<10$ years.

Table 4 summarizes the comparison of the lung function parameters for rice mill workers and their control group. There was significant difference in spirometry findings (FVC, $\mathrm{FEV}_{1}, \mathrm{FEV}_{1} / \mathrm{FVC}$ ratio, PEFR) between the rice mill workers and controls. Rice mill workers exposed to dust presented significantly $(p<0.05)$ lower levels of FVC $(3.44 \pm 0.11), \quad \mathrm{FEV}_{1} \quad(2.73 \pm 0.15), \quad$ and $\quad$ PEFR

Table 2 Respiratory symptoms in 120 rice mill workers and 50 controls

\begin{tabular}{lllll}
\hline Symptoms & $\begin{array}{l}\text { Rice mill } \\
\text { workers, No. }(\%)\end{array}$ & $\begin{array}{l}\text { Controls, } \\
\text { No. }(\%)\end{array}$ & $\chi^{2}$ & $p$ value \\
\hline Chest tightness & $32(26.7)$ & $1(2)$ & 12.2 & $<0.05$ \\
Phlegm & $49(40.8)$ & $2(4)$ & 21.08 & $<0.05$ \\
Cough & $26(21.7)$ & $1(2)$ & 8.79 & $<0.05$ \\
Dyspnea & $53(44.2)$ & $1(2)$ & 27.0 & $<0.05$ \\
Eye burning & $78(65.0)$ & $3(6)$ & 46.9 & $<0.05$ \\
Nose irritation & $33(27.5)$ & $1(2)$ & 12.8 & $<0.05$ \\
\hline
\end{tabular}

Table 3 Distribution of respiratory symptoms in 120 rice mill workers by duration of employment

\begin{tabular}{lcrlcll}
\hline $\begin{array}{l}\text { Respiratory } \\
\text { symptoms }\end{array}$ & \multicolumn{2}{l}{ Duration of employment (years) } & $\chi^{2}$ & $p$ value \\
\cline { 2 - 4 } & $<10$ & $10-19$ & $\geq 20$ & & \\
& $N=47$ & $N=31$ & $N=42$ & & \\
& No. $(\%)$ & No. $(\%)$ & No. (\%) & & \\
\hline Chest tightness & $9(29)$ & $5(10.6)$ & $18(42.9)$ & 8.74 & $<0.05$ \\
Phlegm & $11(35.5)$ & $14(29.8)$ & $24(57.1)$ & 10.77 & $<0.05$ \\
Cough & $7(22.6)$ & $7(14.9)$ & $12(28.6)$ & 2.465 & $<0.05$ \\
Dyspnea & $16(51.6)$ & $8(17.0)$ & $29(69.0)$ & 16.73 & $<0.05$ \\
Eye burning & $21(56.8)$ & $19(40.4)$ & $38(90.5)$ & 20.7 & $<0.05$ \\
Nose irritation & $6(19.4)$ & $10(21.3)$ & $14(33.3)$ & 6.17 & $<0.05$ \\
\hline
\end{tabular}


(304.95 \pm 28.79$)$ than the controls, except \%FEV1/FVC as shown in Table 4.

Table 5 shows the changes in the lung volume of the rice mill workers by duration of employment. By ANOVA, it was found that there is a significant difference $(p<0.05)$ in lung volumes $\left(\mathrm{FEV}_{1}, \mathrm{FVC}, \mathrm{FEV}_{1} / \mathrm{FVC}\right.$ ratio, PEFR) among the rice mill workers depending on their duration of work experience. Rice mill workers exposed for $>20$ years, showed a significant reduction in FVC (3.10 \pm 0.31$)$, $\mathrm{FEV}_{1}$ (2.21 \pm 0.19$), \quad \mathrm{FEV}_{1} / \mathrm{FVC}$ ratio (72.04 \pm 2.84$)$, PEFR (300.03 \pm 31.09$)$ compared to the workers with less duration of work experience.

Hematological signs like absolute eosinophil counts, total IgE and ESR in rice mill workers and normal controls are presented in Table 6 . The rice mill workers have significantly higher AEC $(369 \pm 14.24)$, total $\mathrm{IgE}$ $(137 \pm 21.11)$ and ESR $(18 \pm 0.74)$ than the control group AEC $(189 \pm 17.37)$, total $\operatorname{IgE}(48 \pm 14.62)$ and ESR $(7 \pm 0.62)$. Eosinophilia was observed in $(26.7 \%) 32$ rice mill workers, whereas only 2 (4\%) controls were identified with having eosinophilia.

Table 4 Lung function test parameters in 120 rice mill workers and 50 controls

\begin{tabular}{lcrrr}
\hline Parameters & $\begin{array}{l}\text { Rice mill workers } \\
(\text { mean } \pm \text { SD) }\end{array}$ & \multicolumn{1}{l}{$\begin{array}{l}\text { Controls } \\
(\text { mean } \pm \text { SD) }\end{array}$} & $t$ value & $p$ value \\
\hline FVC $(1)$ & $3.44 \pm 0.11$ & $4.56 \pm 0.18$ & 49.56 & $<0.05$ \\
$\mathrm{FEV}_{1}(1)$ & $2.73 \pm 0.15$ & $3.58 \pm 0.18$ & 31.69 & $<0.05$ \\
$\% \mathrm{FEV}_{1} /$ & $79.02 \pm 3.24$ & $74.24 \pm 1.93$ & 9.72 & $<0.05$ \\
$\quad \mathrm{FVC}$ & & & & \\
$\begin{array}{l}\text { PEFR } \\
(1 / \mathrm{min})\end{array}$ & $304.95 \pm 28.79$ & $364.5 \pm 21.71$ & 13.14 & $<0.05$ \\
\hline
\end{tabular}

The proportions of workers with radiological abnormalities are given in Table 7, from which it may be seen that a significantly greater proportion of rice mill workers had chest opacities with or without increased reticulation.

The comparison of radiological findings among rice mill workers with the control group is shown on Table 7. From the Table 7 , it was observed that there was a significant change $(p<0.05)$ in nodulation between rice mill workers and control subjects, whereas in case of fibrosis no change has been observed in between rice mill workers and control subjects.

The opacities consisted mainly of fine nodulation (14.2\%) in the upper and mid-zones of the lungs (Fig. 1), but one worker also had a large nodule $1 \mathrm{~cm}$ in diameter. Four cases had a diffuse haze that made recognition of the lung parenchyma difficult. Fine calcification was also seen in two cases; one case showed fibrosis with obstructive lung pattern (Fig. 2).

\section{Discussion}

Rice mill dust contains husk and may contain a large number of contaminants including silica, fungi and their metabolites (aflatoxin), bacterial endotoxins, insects. Therefore, the workers who work for more than $8 \mathrm{~h}$ daily in this type of mill are at high risk of inhaling the spores or fragments of mycelium containing aflatoxin [30-32]. Although aflatoxins are well known as a potent hepatotoxin and hepatocarcinogen, recent study has revealed their possible role through the respiratory route [30].

In this current study it was found that, a significantly higher prevalence of respiratory symptoms such as cough, phlegm, tightness, dyspnea and eye burning in workers

Table 5 Distribution of lung function test parameters in 120 rice mill workers by duration of employment

\begin{tabular}{|c|c|c|c|c|c|c|c|c|c|}
\hline \multirow[t]{2}{*}{ Parameters } & \multicolumn{3}{|c|}{ Duration of employment (years) } & \multirow[t]{2}{*}{$F$ value } & \multirow[t]{2}{*}{$p$ value } & \multicolumn{4}{|c|}{ Post hoc multiple comparison tests } \\
\hline & $\begin{array}{l}N=47 \\
<10 \\
(\text { mean } \pm \mathrm{SD})\end{array}$ & $\begin{array}{l}N=31 \\
10-19 \\
(\text { mean } \pm \mathrm{SD})\end{array}$ & $\begin{array}{l}N=42 \\
\geq 20 \\
(\text { mean } \pm \mathrm{SD})\end{array}$ & & & Comparison & $P$ value & SE & $P<0.05$ \\
\hline \multirow[t]{3}{*}{ FVC (1) } & $4.01 \pm 0.14$ & $3.52 \pm 0.23$ & $3.10 \pm 0.31$ & 167.90 & 0.000 & 1 vs. 3 & 18.3 & 0.03 & Yes \\
\hline & & & & & & 1 vs. 2 & 9.0 & 0.03 & Yes \\
\hline & & & & & & 2 vs. 3 & 7.6 & 0.03 & Yes \\
\hline \multirow[t]{3}{*}{$\mathrm{FEV}_{1}(1)$} & $3.08 \pm 0.41$ & $2.81 \pm 0.32$ & $2.21 \pm 0.19$ & 82.11 & 0.000 & 1 vs. 3 & 12.6 & 0.04 & Yes \\
\hline & & & & & & 1 vs. 2 & 3.60 & 0.05 & Yes \\
\hline & & & & & & 2 vs. 3 & 7.82 & 0.05 & Yes \\
\hline \multirow[t]{3}{*}{$\% \mathrm{FEV}_{1} / \mathrm{FVC}$} & $76.25 \pm 3.02$ & $79.14 \pm 3.24$ & $72.04 \pm 2.84$ & 51.62 & 0.000 & 1 vs. 3 & 9.93 & 0.50 & Yes \\
\hline & & & & & & 1 vs. 2 & 4.14 & 0.49 & Yes \\
\hline & & & & & & 2 vs. 3 & 6.57 & 0.45 & Yes \\
\hline \multirow[t]{3}{*}{ PEFR (1/min) } & $325.25 \pm 29.2$ & $311.05 \pm 32.0$ & $300.0 \pm 31.0$ & 7.63 & 0.000 & 1 vs. 3 & 3.89 & 4.59 & Yes \\
\hline & & & & & & 1 vs. 2 & 2.00 & 5.00 & No \\
\hline & & & & & & 2 vs. 3 & 1.52 & 5.11 & No \\
\hline
\end{tabular}


Table 6 Hematological and immunological parameters in 120 rice mill workers and 50 controls

\begin{tabular}{lccccc}
\hline Parameters & $\begin{array}{l}\text { Rice mill workers } \\
(\text { mean } \pm \text { SD) }\end{array}$ & $\begin{array}{l}\text { Controls } \\
(\text { mean } \pm \text { SD) }\end{array}$ & $t$ value & $95 \%$ CI & $p$ value \\
\hline $\begin{array}{l}\text { Absolute eosinophil count } \\
\left(\text { cells } / \mathrm{mm}^{3}\right)\end{array}$ & $369 \pm 14.24$ & $189 \pm 17.37$ & 70.26 & $174.9-185.1$ & $<0.05$ \\
Total $\mathrm{IgE}(\mathrm{IU} / \mathrm{ml})$ & $137 \pm 21.11$ & $48 \pm 14.62$ & 27.20 & $82.54-95.46$ & $<0.05$ \\
ESR $(\mathrm{mm} / \mathrm{h})$ & $18 \pm 0.74$ & $7 \pm 0.62$ & 92.41 & $10.77-11.23$ & $<0.05$ \\
\hline
\end{tabular}

Table 7 Radiological findings in 120 rice mill workers and 50 controls

\begin{tabular}{lllll}
\hline Parameters & $\begin{array}{l}\text { Rice mill } \\
\text { workers no. (\%) }\end{array}$ & $\begin{array}{l}\text { Controls } \\
\text { no. (\%) }\end{array}$ & $\chi^{2}$ & $p$ value \\
\hline Nodulation & $17(14.2)$ & $2(4)$ & 2.72 & 0.099 \\
Fibrosis & $6(5)$ & $1(2)$ & 0.22 & 0.636 \\
\hline
\end{tabular}

related to duration of employment exposure especially higher than 20 years. In other studies similar respiratory symptoms cough (30\%), phlegm (25\%), dyspnea (21\%) were reported among workers at a cement factory in a rapidly developing country [33].

Numerous studies have investigated the respiratory health effects of exposure to cotton dust in textile industries. Exposure to cotton dust has been reported to be associated with cough and dyspnea [34]. In our study, respiratory difficulties such as tightness of chest, cough and phlegm may be allergic responses, either to a protein constituent of the rice husk or to some microbiological contaminant.

Workers exposed to husk dust during milling, transfer operations, mixing processes may develop respiratory diseases [35, 36] demonstrating the relation between dust exposure levels and the respiratory health status of workers in grain and flour mills and a dose-response relationship between dust exposure levels and chronic respiratory symptoms was observed, suggesting that exposure to grain and flour dust may lead to chronic bronchitis. Studies of Gimenez et al. [37] reported that, exposure to flour dust may induce chronic respiratory manifestations as well as low pulmonary function values among mill workers by comparison with referents. In addition, studies of Von Essen [38], demonstrated that grain dust exposure is a common cause of respiratory symptoms and these workers showed obstructive changes on pulmonary function testing. Similarly, we observed obstructive type changes in lung function tests in flour mill workers compared to controls. Rice mill workers exposed to husk dust presented significantly $(p<0.05)$ lower levels of FVC, FEV1 and PEFR than controls, except \%FEV1/FVC as shown in Table 4. It might be considered that, the reason behind \% FEV1/FVC was lower in rice mill workers than controls is due to the decreased FVC. These workers may find it impossible to

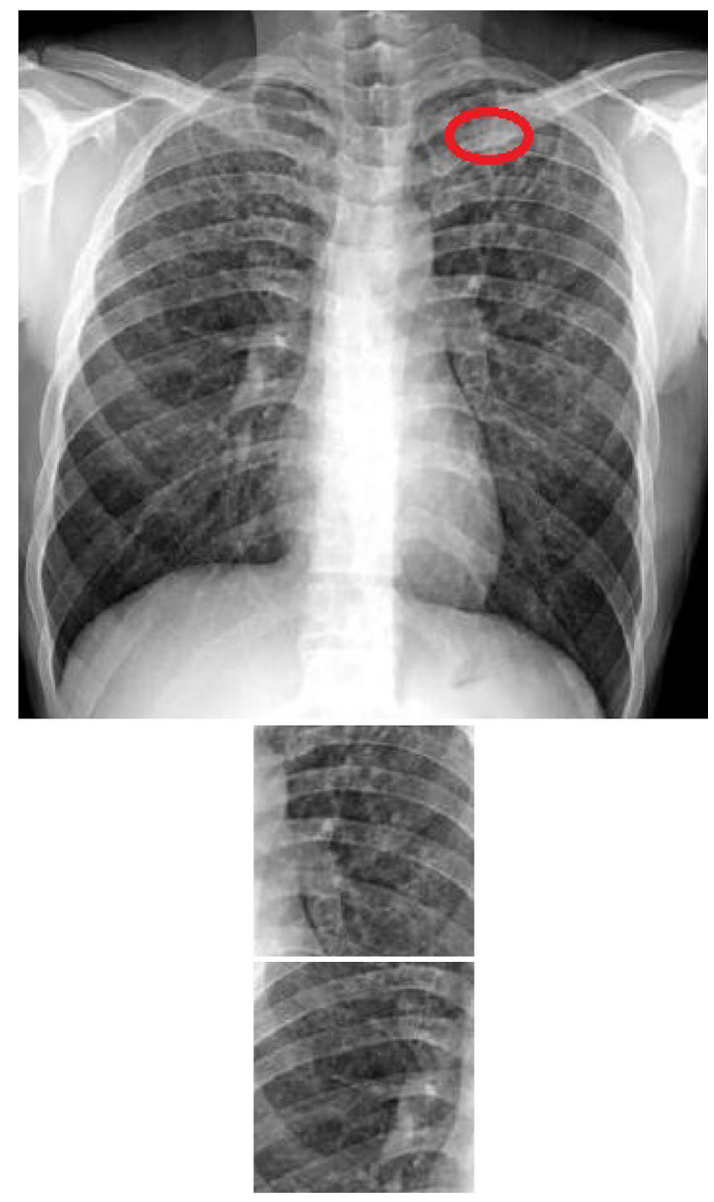
reticular markings with calcifications in left upper zone and right midzone

exhale fully, since their respiration is limited by their symptoms. Therefore, the ratio of FEV1 and FVC in workers resulted to be higher than controls. In different words, long-term workers presented severe reduction of FEV1 as well as similar severe decrease of FVC, too, as shown in Table 5. Corzo and Naveda [39] observed spirometric changes due to high concentrations of wheat dust at a wheat processing plant in anthropometrically matched subjects. They reported a decrease in the peak flow rate (PFR), forced expiratory volume (FEV \%). Similarly, our results for lung function confirm the results observed by Corzo and Naveda [39], it measured lung functions in
Fig. 1 Chest X-ray of a rice mill worker showing bilateral enhanced 


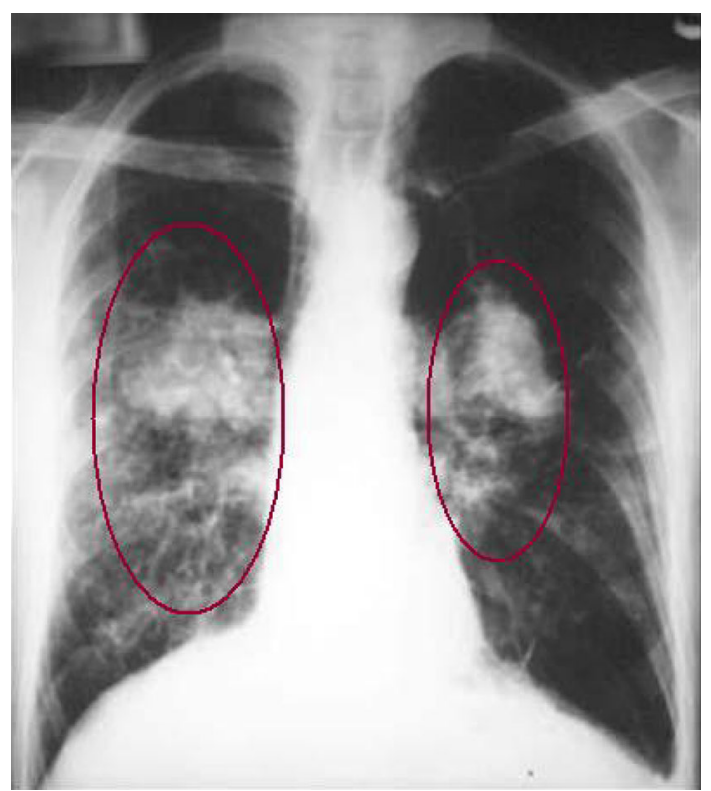

Fig. 2 Chest X-ray of a rice mill worker showing extensive fibrosis in both mid-zones and bilateral hyperinflated lungs and tubular heart shadow

workers exposed to flour dust showed a significant drop in the forced expiratory volume in $1 \mathrm{~s}\left(\mathrm{FEV}_{1}\right)$ and forced vital capacity (FVC). The declines in lung volumes are significantly associated with the duration of exposure [40]. In the present study, results for FVC, $\mathrm{FEV}_{1}$ and PEFR confirm the results observed by Zodpey and Tiwari [41], which showed an annual decline in forced expiratory volume in $1 \mathrm{~s}$ $\left(\mathrm{FEV}_{1}\right)$. These parameters were significantly related to occupational exposure to dust in grain processing industry. In this current study, rice mill workers exposed for $>20$ years showed a significant reduction in FVC, $\mathrm{FEV}_{1}$, $\mathrm{FEV}_{1} / \mathrm{FVC}$ ratio, PEFR compared to the workers with less duration of work experience. The present study confirms the findings of others and suggests that rice husk dust adversely affects lung function parameters, such as FVC, FEV $_{1}$ and PEFR suggesting an obstructive pattern of lung function impairment which is associated with the doseeffect of years of exposure to husk dust.

Hematological signs like absolute eosinophil counts, total IgE and ESR in rice mill workers were significantly higher than the control group. Eosinophilia was observed in 32 rice mill workers $(26.7 \%)$ in the current study. Di Lorenzo et al. [42] reported that there is an inter-relationship of the allergen type, total serum IgE, eosinophil and bronchial hyper-responsiveness suggesting that all three may play a role in the development of bronchial asthma. According to Halonen et al. [43], a significant relationship exists between serum IgE levels and eosinophilia in populations presumed to be free of parasites where IgE levels presumably provide a better clue to atrophy than skin tests.
The higher IgE level in rice mill workers is explained probably by the higher incidence of parasitic infestations or being affected by chronic allergic substances. Based on the current study, it can be presumed that elevated total serum IgE levels and absolute eosinophil counts and ESR in rice mill workers were the result of occupational inhalation of rice mill dust containing husk, contaminants including silica, fungi and their metabolites (aflatoxin).

The most important finding in the current study is the demonstration of chest opacities on radiological examination. The predominant pattern was fine nodulation and enhanced reticulation, mainly in the upper and mid-zones of the lungs, with diffuse haze in some cases. Fine calcification was also seen in two cases; one case showed both fibrosis with obstructive lung pattern. Rice husk has been known to have a high silica content [30,31], which has been used for its abrasive action as detergents, dyes, and even as cleansing agents. The nodular shadows may thus represent the early stages of silicosis, although the distribution appears uncharacteristic of classical silicosis. On the other hand, extrinsic allergic alveolitis may also produce these radiological features.

The findings are of importance in that they demonstrate the extensive need for preventive measures. It is advisable therefore for rice mill workers to adopt technical preventive measures, such as having well-ventilated work areas and wearing appropriate respiratory protective devices. These measures will help in preventing lung damage, which often, over time, contributes to morbidity and mortality. It is also suggested that rice mill workers must undergo periodic medical surveillance tests. These tests will identify susceptible workers, so that they can take adequate preventive measures as well as medication.

Acknowledgments The authors express their sincere gratitude to all the rice mill workers and control subjects for their immense cooperation during this study.

Conflict of interest None declared.

\section{References}

1. Czeslawa S, Barbara M, Jacek D, Ewa KT, Janusz M, Helen F, et al. Effects of exposure to grain dust in polish farmers: work related symptoms and immunological response to microbial antigens associated with dust. Ann Agric Environ Med. 1998;5:147-53.

2. Mengesha A, Bekele A. Relative chronic effects of occupational dusts on respiratory indices and health of workers in three Ethiopian factories. Am J Ind Med. 1998;34:373-80.

3. Imbus HR. Clinical aspects of occupational medicine. In: Carl Zenz, Bruce Dickerson O, Horvath EP Jr. (Eds) Occupational medicine, 3. Third edition. London: Mosby; 1994.

4. Musal R, Naingl L, Ahmadl Z, Kamarul Y. Respiratory health of rice millers in Kelantan, Malaysia. Southeast Asian J Trop Med Public Health. 2000;31(3):575-8. 
5. Glyseth B, Stettler L, Mowe G, Skaug V, Lexow P. A striking deposition of mineral particles in the lungs of a farmer: a case report. Am J Ind Med. 1984;6:231-40.

6. Green FH, Yoshida K, Fick G, Paul J, Hugh A, Green WF. Characterization of airborne mineral dusts associated with farming activities in rural Alberta, Canada. Int Arch Occup Environ Health. 1990;62:423-30.

7. Sherwin RP, Barman ML, Abraham JL. Silicate pneumoconiosis of farm workers. Lab Invest. 1979;40(5):576-82.

8. Hurst TS, Dosman JA. Characterization of health effects of grain dust exposures. Am J Ind Med. 1990;17:27-32.

9. Hoppin JA, Valcin M, Henneberger PK, Kullman GJ, Umbach DM, London SJ, et al. Pesticide use and chronic bronchitis among farmers in the agricultural health study. Am J Ind Med. 2007;50:969-79.

10. Schenker MB. Respiratory health hazards in agriculture. American Thoracic Society Consensus Report. Am J Respir Crit Care Med. 1998;158(suppl 4):S1-76.

11. Wolf C, Pirich C, Valic E, Waldhoer T. Pulmonary function and symptoms of welders. Int Arch Occup Environ Health. 1997;69:350-3.

12. Sullivan JB, Krieger GR, editors. Hazardous materials toxicology: clinical principles of environment health. Baltimore, Maryland: Williams and Wilkins; 1992.

13. Nakadate T, Aizawa Y, Yagami T, Zheg YQ, Kotani M, Ishiwata $\mathrm{K}$. Change in obstructive pulmonary function as a result of cumulative exposure to welding fumes as determined by magnetopneumography in Japanese arc welders. Occup Environ Med. 1998;55:673-7.

14. Burge PS. Occupation and chronic obstructive pulmonary disease (COPD). EurRespir J. 1994;7:1032-4.

15. Barker RD, Van Tongeren MJ, Harris JM, Gardiner K, Venables KM, Taylor NAJ. Risk factors for sensitization and respiratory symptoms among workers exposed to acid anhydrides: a cohort study. Occup Environ Med. 1998;55:684-91.

16. Morgan W, Seaton A. Occupational lung diseases. Philadelphia: Saunders Company; 1995. p. 82-110.

17. Mustaibegovic J, Zuskin E, Schachter EN, Kern J, Luburic-Milas M, Pucarin J. Respiratory findings in tobacco workers. Chest. 2003;123:1740-9.

18. Grammer LC. Occupational allergic alveolitis. Ann Allergy Asthma Immunol. 1999;12:602-6.

19. Lacey J, Dutkiewicz J. Bio-aerosols and occupational lung disease. J Aerosol Sci. 1994;25:1371-404.

20. Milanowski J. Organic dust-induced lung diseases. Current Pneumol. 1998;2:15-20.

21. Rylander R, Jacobs RR. Organic dusts. Exposure, effects and prevention. Boca Raton: Lewis Publishers; 1994.

22. Post W, Heederik D, Houba R. Decline in lung function related to exposure and selection processes among workers in grain processing and animal feed industry. Occup Environ Med. 1998;55:349-55.

23. Schwartz DA, Thorne PS, Yagla SJ, Burmeister LF, Olenchock SA, Watt JL, et al. The role of endotoxin in grain dust-induced lung disease. Am J Respir Crit Care Med. 1995;152:603-8.

24. Zock JP, Hollander A, Heederik D, Douwes J. Acute lung function changes and low endotoxin exposures in the potato processing industry. Am J Ind Med. 1998;33:384-91.
25. Zuskin E, Mustajbegovic J, Schachter EN. Follow-up study of respiratory function in hemp workers. Am $\mathrm{J}$ Ind Med. 1994;26:103-15.

26. Ruppel GL. Pulmonary function testing trends and techniques. Resp Care Clin N Am. 1997;3:155-81.

27. Mandryk J, Alwis KU, Hocking AD. Work-related symptoms and dose response relationships for personal exposures and pulmonary function among woodworkers. Am $\mathrm{J}$ Ind Med. 1999;35:481-90.

28. Mandryk J, Alwis KU, Hocking AD. Effects of personal exposures on pulmonary function and work-related symptoms among sawmill workers. Ann Occup Hyg. 2000;44:281-9.

29. Das B, Ghosh T, Gangopadhyay S. Peak expiratory flow rate among child labourers in West Bengal, India. Indian Pediatr. 2011;48:487-8.

30. Desai MS, Ghosh SK. Aflatoxin related occupational hazards among rice mill workers. J Toxicol Toxin Rev. 1989;8:81-8.

31. Parkes WR. Occupational lung disorders. London: Butter Worths; 1980.

32. Desai MS, Ghosh SK. Aflatoxin related occupational exposure to maize processing workers. Cell Mol Biol (Noisy-le-grand). 2003;49(4):529-35.

33. Bakkert P, Eide GE, Hanoa R, Gulsvik A. Occupational dust or gas exposure and prevalences of respiratory symptoms and asthma in a general population. Eur Respir J. 1991;4:273-8.

34. Wang XR, Eisen EA, Zhang HX, Sun BX, Dai HL, Pan LD, et al. Respiratory symptoms and cotton dust exposure; results of a 15-year follow up observation. Occup Environ Med. 2003;60:935-41.

35. Yach D, Myers J, Bradshaw D, Merriman JE. A respiratory epidemiological survey of grain mill workers in Cape Town, South Africa. Am Rev Resp Dis. 1985;131:505-10.

36. Massin N, Bohadana AB, Wild P, Kolopp-Sarda MN, Toamain JP. Air way responsiveness to methacholine, respiratory symptoms, and dust exposure levels in grain and flour mill workers in eastern France. Am J Ind Med. 1995;27:859-69.

37. Gimenez C, Fouad K, Choudat D, Laureillard J, Bouscaillou P, Leib E. Chronic and acute respiratory effects among grain mill workers. Int Arch Occup Environ Health. 1995;67:311-5.

38. Von Essen S. The role of endotoxin in grain dust exposure and airway obstruction. Curr Opin Pulm Med. 1997;3:198-202.

39. Corzo G, Naveda R. Spirometry in workers in a wheat-processing industry. Invest Clin. 1998;39:175-87.

40. Ige OM, Awoyemi OB. Respiratory symptoms and ventilatory function of the bakery workers in Ibadan, Nigeria. West Afr $\mathbf{J}$ Med. 2002;21:316-8.

41. Zodpey SP, Tiwari RR. Peak expiratory flow rate in flour mill workers. Indian J Physiol Pharmaco. 1998;42:521-6.

42. Di Lorenzo G, Mansuetop Melluso M, Morici G, Norrito F, Esposito Pellitteri M, et al. Non-specific airway hyper responsiveness in monosensitive Sicilian patients with allergic rhinitis: Its relationship to total serum IgE level and blood eosinophils during and out of the pollen season. Clin Exp Allergy. 1997;27:1052-9.

43. Halonen M, Barbee RA, Lehanitz MD, Eurrows B. An epidemiologic study of the interrelationship of total serum immunoglobulin E, Allergy skin reactivity and eosinophils. J Allergy Clin Immunol. 1982;69:221-8. 